\title{
Civil Society Organizations di Aras Lokal
}

\author{
Linayati Lestari \\ Program Studi Ilmu Pemerintahan Fakultas Ilmu Sosial dan Ilmu Politik \\ Universitas Riau Kepulauan, Batam Indonesia \\ linayatilestari@yahoo.com
}

\begin{abstract}
This articleattemps like to see the characteristics of CSOs in Indonesia, to see the extent to which their participation in the formulation of public policy and what factors influence it. This paper shows that the involvement of NGOs in the formulation of public policy by the local government tends only as a legitimate need only, that what has been decided has been done by involving the community. It is deliberately conditioned to perpetuate the dominance of LGs and DPRDs in the preparation of APBD. Whereas CSOs/NGOs in carrying out their activities still have internal constraints and weaknesses, namely lack of experience in doing advocacy works, weaknesses in network building and also influenced by the response of local government and also by donor agencies. This condition has implications for the non-participation of CSOs in the process of public policy formulation in Indonesia. In a democratic system of government, the concept of community participation is one important concept because it is directly related to the nature of democracy as a government system that focuses on the people as the holder of sovereignty. In the context of the formulation of public policy participation becomes a key word that must be realized and practiced by the Local Government so that public policy is no longer a matter of the Regional Government alone. The change in political concomitants following the postNew Order political decentralization brought enormous implications for local politics. The regional government in this case has no choice but to reform the good governance.
\end{abstract}

Keywords: NGO, participation, public policy, local government

\begin{abstract}
Abstrak
Tulisan ini hendak melihat karakteristik CSO di Indonesia, melihat sejauh mana partisipasinya dalam perumusan kebijakan publik serta faktor-faktor apa saja yang mempengaruhinya. Tulisan ini menunjukkan bahwa pelibatan LSM dalam perumusan kebijakan publik oleh Pemerintah daerah cenderung hanya sebagai kebutuhan legitimasi semata, bahwa apa yang diputuskan sudah dilakukan dengan melibatkan masyarakat. Hal ini sengaja dikondisikan untuk melanggengkan dominasi Pemda dan DPRD dalam penyusunan APBD. Bahwa CSO/LSM dalam menjalankan aktifitasnya masih menyimpan kendala dan kelemahan secara internal, yaitu kurangnya pengalaman dalam melakukan kerja-kerja advokasi, kelemahan dalam membangun jaringan serta dipengaruhi pula oleh respon Pemerintah Daerah dan juga oleh lembaga donor. Kondisi ini, membawa implikasi pada tidak maksimalnya partisipasi CSO dalam proses perumusan kebijakan publik di Indonesia. Dalam sistem pemerintahan yang demokratis, konsep partisipasi masyarakat merupakan salah satu konsep yang penting karena berkaitan langsung dengan hakikat demokrasi sebagai sistem pemerintahan yang berfokus pada rakyat sebagai pemegang kedaulatan. Dalam konteks perumusan kebijakan publik partisipasi menjadi kata kunci yang harus diwujudkan dan dipraktekkan oleh Pemerintah Daerah sehingga kebijakan publik tidak lagi menjadi persoalan Pemerintah Daerah semata. Perubahan konstalasi politik menyusul desentralisasi politik pasca Orde Baru membawa implikasi yang sangat besar pada perpolitikan lokal. Pemerintah Daerah dalam hal ini tidak mempunyai pilihan lain kecuali melakukan pembaharuan menuju tata kelola pemerintahan yang baik (good governance).
\end{abstract}

Kata Kunci : LSM, partisipasi, kebijakan publik, pemerintah daerah

\section{PENDAHULUAN}


Perubahan konstalasai politik sebagai buah dari gerakan reformasi membawa implikasi yang cukup signifikan bagi demokratisasi di Indonesia. Dalam situasi keterbukaan politik hasil gerakan reformasi nasional, kemudian bermunculan tuntutan dan aspirasi masyarakat di beberapa daerah tentang perlunya pemerintahan sendiri agar dapat mempercepat kemajuan masyarakat. Tuntutan tersebut kemudian kita kenal dengan keinginan untuk berotonomi melalui pemekaran berbagai daerah baik provinsi maupun kabupaten/kota. Momentum keterbukaan politik pasca orde baru benar-benar dimaknai sebagai momentum penting bagi kemunculan LSM dengan berbagai perannya. Kehadiran LSM dalam masyarakat merupakan kenyataan yang tidak dapat dipungkiri.

Hal ini disebabkan oleh keterbatasan peran dan kapasitas pemerintah disemua sektor pembangunan, sehingga tidak semua aspirasi dan kebutuhan masyarakat dapat dipenuhi oleh pemerintah. Dalam kondisi demikian itulah kehadiran LSM dipandang memberikan kontribusi penting dimasyarakat, walaupun kadangkala kegiatan-kegiatan yang dilakukan oleh LSM cenderung menjadi pesaing bagi kegiatan-kegiatan yang dilakukan oleh pemerintah sehingga seringkali menimbulkan situasi dimana LSM sering mengalami resistensi dari birokrasi pemerintahan.

Lemahnya fungsi lembaga-lembaga politik seperti lembaga perwakilan dan partai politik, masyarakat kemudian menaruh harapan besar kepada LSM sebagai pilihan alternatif dalam menyalurkan aspirasi dan kepentingan mereka. Kondisi ini menunjukkan bahwa sesungguhnya LSM dapat memanfaatkan peluang yang ada untuk memainkan peran-peran penting dalam proses pembangunan. Kehadiran LSM dalam jumlah relatif banyak memberikan harapan kearah perbaikan, tetapi realitas menunjukkan bahwa walaupun semangat pembentukan LSM yang begitu antusias, pada saat yang sama banyak dari kalangan LSM tersebut yang terjebak dalam kepentingan-kipentingan pragmatis sehingga banyak persoalan-persoalan sosial politik di Indonesia yang tidak tertangani dengan baik, disamping itu kehadiran LSM yang cukup banyak tersebut ternyata belum mampu membawa perubahan berarti dalam pembaharuan tata pemerintahan di Indonesia. Fungsi pelayanan publik masih belum terjadi perbaikan berarti, korupsi masih menjadi momok yang menakutkan, kemiskinan dan keterbelakangan belum dapat ditangani dengan seksama serta sejumlah permasalahan sosial kemasyarakatan yang belum tertangani secara baik pasca konflik sosial. 


\section{KONSEP PARTISIPASI POLITIK}

Partisipasi politik secara umum dapat diartikan sebagai kegiatan seseorang atau sekelompok orang untuk ikut secara aktif dalam politik yaitu dengan jalan memilih pemimpim negara secara langsung atau mempengaruhi kebijakan pemerintah (Miriam Budiardjo, 1982). Huntington dan Nelson (Samuel P. Huntington dan Joan, 1994) mendefenisikan partisipasi politik sebagai kegiatan warga negara (private citizen) yang bertujuan untuk mempengaruhi pengambilan keputusan pemerintah. Partisipasi politik mencakup semua kegiatan politik warga negara yang ditujukan untuk mempengaruhi aktivitas kebijakan pemerintah, kegiatan mana dilatarbelakangi oleh adanya keinginan warga negara agar kebijakan-kebijakan yang diambil pemerintah akomodatif terhadap kepentingan mereka. Terdapat beberapa aspek pokok yang terkandung dalam pengertian partisipasi politik menurut Sastroatmodjo (Sudjono Sastroatmodjo, 1995), yaitu :

1. Partisipasi hanyalah mencakup kegiatan-kegiatan dan bukan sikap-sikap;

2. Yang dimaksud dalam partisipasi politik adalah warga negara biasa bukan pejabat-pejabat pemerintah;

3. Kegiatan partisipasi politik adalah kegiatan yang mempengaruhi pengambilan keputusan pemerintah;

4. Partisipasi politik juga mencakup semua kegiatan yang mempengaruhi pemerintah, terlepas dari tindakan tersebut efektif atau tidak, berhasil atau gagal;

5. Partisipasi politik berupa kegiatan mempengaruhi yang dilakukan secara langsung maupun tidak langsung.

Selanjutnya Sastroatmodjo mengemukakan bahwa partisipasi politik dapat dibedakan atas partisipasi individual dan partisipasi kolektif. Partisipasi individual adalah yang dilakukan secara perorangan oleh warga negara yang pada umumnya dilakukan secara konvensional (biasa) misalnya, dengan mengajukan tuntutan dan keluhan melalui surat kepada pemerintah. Sedangkan partisipasi kolektif adalah kegiatan yang dilakukan secara bersama-sama oleh warga negara baik secara konvensional maupun non konvensional. Partisipasi konvensional meliputi pemberian suara (voting), aktivitas diskusi politik, kegoatan kampanye, aktivitas membentuk dan bergabung dengan kelompok kepentingan lain dan komunikasi dengan pejabat politik. Sedangkan partisipasi non konvensional (agresif) meliputi; pengajuan petisi, demontrasi, konfrontasi, pemogokan dan serangkaian tindakan kekerasan seperti perusakan, pemboman dan pembakaran. 
Dalam pandangan Milbrath dan Goel (Ramlan Surbakti, 1999) partisipasi politik dapat dikategorikan berdasarkan derajat keaktifan pihak yang berpartisipasi, yakni:

1. Apatis, yakni orang yang tidak berpartisipasi atau menarik diri dari proses politik;

2. Spektator, yakni orang yang setidak-tidaknya pernah ikut dalam kegiatan pemilihan umum;

3. Gladiator, yaitu mereka yang secara aktif terlibat dalam proses politik sebagai; komunikator, spesialis mengadakan tatap muka, aktifis dan pekerja kampanye dan aktifis masyarakat;

4. Pengkritik, yakni orang yang berpartisipasi dalam bentuk yang tidak konvensional.

\section{DIMENSI TEORITIK KEBIJAKAN PUBLIK}

Terminologi kebijakan publik merujuk pada rangkaian keputusan dan tindakan yang diambil oleh pemerintah dalam mengatasi persoalan-persoalan yang dihadapi masyarakat. Namun menurut Thomas R. Dye (Budi Winarno, 2002), kebijakan publik tidak semata-mata menyangkut keputusan dan tindakan nyata pemerintah, melainkan juga mencakup pilihan pemerintah untuk tidak melakukan tindakan terhadap suatu persoalan. Jadi kebijakan publik lebih menggambarkan posisi pemerintah terhadap suatu persoalan publik. Anderson (Budi Winarno, 2002) mengemukakan beberapa implikasi yang terkandung dalam konsep kebijakan publik, yaitu :

1. Kebijakan publik selalu berorientasi pada maksud dan tujuan tertentu;

2. Kebijakan publik merupakan arah atau pola tindakan pemerintah;

3. Kebijakan publik adalah apa yang sebenarnya dilakukan pemerintah bukan apa yang diinginkan pemerintah;

4. Kebijakan publik mungkin dalam bentuknya bersifat positif atau negatif. Secara positif kebijakan mungkin mencakup bentuk tindakan pemerintah yang jelas untuk mempengaruhi masalah tertentu. Secara negatif, kebijakan mungkin mencakup suatu keputusan oleh pejabat-pejabat pemerintah tetapi tidak untuk melakukan sesuatu mengenai suatu persoalan yang memerlukan keterlibatan pemerintah.

Pembuatan kebijakan publik dapat dianalisis dalam berbagai model, satu diantaranya adalah model sistem yang dikembangkan berdasarkan pendekatan sistem politik yang 
dikemukakan oleh David Easton(Oberlin Silalahi, 1989). Asumsi dasar model ini bahwa dalam pembuatan kebijakan terjadi interaksi yang terbuka dan dinamis antara pembuatan kebijakan dan lingkungannya. Interaksi yang terjadi adalah dalam bentuk masukan dan keluaran (input dan output). Masukan (input) adalah kekuatan yang berasal dari lingkungan sistem politik yang dapat berwujud tuntutan (demand) atau dukungan (support), sedangkan keluaran (output) adalah merupakan hasil (resultante) dari berbagai kekuatan politik yang terlibat dalam perjuangan menegakkan kepentingan yang diwujudkan dalam berbagai bentuk produk kebijakan publik (Purwo Santoso, 1993).

Input yang berupa tuntutan tidak lain adalah permasalahan-permasalahan aktual yang dihadapi masyarakat yang memerlukan penanganan oleh pemerintah. Sedangkan dukungan adalah usaha-usaha masyarakat untuk menunjang agar tuntutan itu dapat direalisasikan oleh sistem politik. Akumulasi dari tuntutan dan dukungan elit perwakilan langsung dalam badan legislatif dan birokrasi serta saluran formal dan institusional lain seperti media masa, radio, surat kabar, televisi dan majalah (Purwo Santoso, 1993). Organisasi yang otonom tentu saja tidak akan terikat pada saluran tertentu saja melainkan cenderung memilih saluran yang dianggap paling efektif. Sementara teknik yang digunakan untuk menjalankan fungsi ini antara lain adalah lobbying, mass propaganda, grass-rooth pressure(Wise Cumming, 1996). Lobbying merujuk pada upaya informal untuk mempengaruhi pembuatan kebijakan dengan mengadakan komunikasi langsung dengan pihak-pihak yang terlibat dalam pembuatan kebijakan, mass propanganda adalah usaha untuk menarik perhatian dengan melemparkan isu kepada publik sedangkan grass-rooth pressure adalah penggalangan masa untuk memberikan tekanan kepada pembuat kebijakan.

\section{LSM DAN KEBIJAKAN PUBLIK}

Menurut Genie-Rochman (Bonnie Setiawan, 2006) jenis LSM yang bersifat "politik" disebut sebagai LSM advokasi. LSM advokasi didefinisikan sebagai "mereka yang kegiatannya bertujuan untuk adanya perubahan dalam kebijakan-kebijakan pemerintah". Menurut dia, ciri-ciri utama LSM advokasi adalah a). target pada badan-badan pemerintah; b). target pada badan-badan internasional; c). adanya strategi advokasi; d). adanya metode advokasi; dan e). adanya tujuan-tujuan transformasi. Isu-isu advokasi juga dilakukan lewat pembentukan opini publik di media massa. Bagi LSM, advokasi bukan hanya alat untuk meningkatkan kondisi kehidupan masyarakat, tetapi juga untuk memperluas ruang politik mereka. 
Untuk memahami hubungan antara LSM dan kebijakan publik maka kebijakan dalam konteks ini adalah dilihat sebagai sebuah fenomena politik sebagaimana ditunjukkan oleh Purwo Santoso (2004) dihubungkan dengan model kelompok. Model kelompok dalam menjelaskan proses pembuatan kebijakan publik berpandangan bahwa interaksi diantara kelompok dalam masyarakat adalah fakta dan fokus kajian utama dari politik dan kebijakan. Politik dalam hal ini adalah persaingan antar kelompok untuk mempengaruhi kebijakan publik. Dengan kata lain bahwa kelompok merupakan jembatan yang paling utama dan terpenting yang menghubungkan antara individu dengan pemerintah sehingga dapat diketahui bahwa politik adalah benar-benar perjuangan diantara kelompok-kelompok yang mempengaruhi proses pembuatan kebijakan publik. Model kelompok ini berusaha untuk menjelaskan semua aktifitas-aktifitas politik yang bermanfaat dan memiliki kaitan dengan perjuangan kelompok sehingga dalam proses pembuatan kebijakan terjadi tekanan, bargaining, negosiasi dan kompromi yang saling bersaing diantara kelompok-kelompok yang berpengaruh (Oberlin Silalahi, 1989).Pembuatan kebijakan publik sebenarnya berlangsung dalam sebuah siklus yang berlangsung secara terus menerus. Siklus dimulai dengan tahapan agenda setting, formulasi, implementasi dan evaluasi.

\section{PARTISIPASI DALAM PERUMUSAN APBD}

Dalam sistem pemerintahan yang demokratis, konsep partisipasi masyarakat merupakan salah satu konsep yang penting karena berkaitan langsung dengan hakikat demokrasi sebagai sistem pemerintahan yang berfokus pada rakyat sebagai pemegang kedaulatan. Partisipasi masyarakat memiliki banyak bentuk, mulai dari yang berupa keikutsertaan langsung masyarakat dalam program pemerintahan maupun yang sifatnya tidak langsung, seperti berupa sumbangan dana, tenaga, pikiran, maupun pendapat dalam pembuatan kebijakan pemerintah. Namun demikian, ragam dan kadar partisipasi seringkali hanya ditentukan secara masif, yakni dari banyaknya individu yang dilibatkan. Padahal partisipasi masyarakat pada hakikatnya akan berkaitan dengan akses masyarakat untuk memperoleh informasi. Hingga saat ini partisipasi masyarakat masih belum menjadi kegiatan tetap dan terlembaga khususnya dalam pembuatan keputusan. Sejauh ini, partisipasi masyarakat masih terbatas pada keikutsertaan dalam pelaksanaan program-program atau kegiatan pemerintah, padahal partisipasi masyarakat tidak hanya diperlukan pada saat pelaksanaan tapi juga mulai tahap perencanaan bahkan pengambilan keputusan. 


\section{Keterlibatan dalam Kegiatan Musrenbangda (Tahap Agenda Setting )}

Salah satu kegiatan perencanaan pembangunan ditingkat daerah provinsi adalah Musyawarah Perencanaan Pembangunan Daerah Provinsi (Musrenbangda) yang dilaksanakan setiap tahun untuk merancang program-program pembangunan daerah. Kegiatan Musrenbangda biasanya dilaksanakan dengan melibatkan sebesar mungkin partisipasi masyarakat sesuai amanat UU Nomor 25 tahun 2004 yang mensyaratkan pelibatan masyarakat dalam proses perencanaan pembangunan nasional maupun pembangunan daerah.

Dalam kaitan itu, bagaimana proses kegiatan Musrenbang berlangsung serta seberapa jauh LSM dapat berperan dalam kegiatan tersebut masih menimbulkan pertanyaan. Musrenbangda Provinsi adalah kegiatan lanjutan. Kegiatan ini adalah merupakan kegiatan berjenjang yang telah dilaksanakan ditingkat kecamatan, kabupaten dan selanjutnya di tingkat Provinsi dan biasanya kegiatan Musrenbangda tidak lebih dari sebuah rutinitas Bappeda yang diselenggarakan setiap tahun. Problem kemudian muncul ketika kegiatan Musrenbang merupakan sebuah rutinitas tahunan Pemda yang sangat formalistik. Dimana pelibatan masyarakat (stakeholders) cenderung untuk memenuhi formalitas semata, karena pendekatan yang digunakan dalam pelaksanaan kegiatan musrenbang adalah pendekatan proyek yang sangat birokratis dan kaku karena semua harus disesuaikan dengan juklak dan juknis yang telah dibuat.

\section{Keterlibatan dalam Pembahasan APBD (Tahap Formulasi)}

APBD adalah salah satu produk kebijakan publik yang menjadi instrumen bagi pemerintah daerah dalam menanggulangi dan menyelesaikan berbagai permasalahan yang dihadapi masyarakat. APBD dirancang dalam satu tahun anggaran untuk menetapkan besaran belanja yang dibutuhkan oleh unit-unit kerja birokrasi pemerintahan. APBD itu sendiri adalah instrumen kebijakan yang sarat dengan nilai informasi karena rencana kerja pemerintah daerah dalam satu tahun beserta tujuan dan sasaran termasuk alokasi dana yang digunakan untuk keperluan itu sepenuhnya tertuang dalam APBD. Oleh karena itu, tahapan-tahapan perumusan APBD seyogyanya dibuat secara terbuka dengan melibatkan partisipasi masyarakat atau dengan kata lain masyarakat harus mempunyai akses informasi terhadap proses perumusan APBD. 


\section{FAKTOR-FAKTOR YANG MEMPENGARUHI PARTISIPASI LSM DALAM PERUMUAN KEBIJAKAN PUBLIK}

Partisipasi LSM dalam perumusan kebijakan publik di Indonesia tidak berdiri sendiri melainkan dipengaruhi oleh berbagai faktor. Faktor-faktor tersebut dapat diidentifikasi berupa faktor yang bersumber dari dalam organisasi itu sendiri yang merupakan faktor internal dan faktor yang barasal dari pengaruh lingkungan atau faktor eksternal. Berdasarkan hasil pengamatan penulis maka dapat diidentifikasi faktor-faktor dimaksud adalah sebagai berikut :

a. Faktor Internal
1) Kapasitas SDM
2) Pengalaman melakukan Advokasi
3) Kapasitas Membangun Jaringan

b. Faktor Eksternal
1) Pandangan dan Sikap Pemda terhadap LSM
2) Faktor Donor 


\section{PENUTUP}

Berdasarkan hasil pengamatan dan pembahasan yang telah diuraikan diatas, dapat disimpulkan hal-hal sebagai berikut : Pertama, Partisipasi CSO dalam perumusan kebijakan publik di Indonesia bila dilihat belum dapat menunjukkan tingkat kedalaman partisipasi yang signifikan. Walaupun demikian prospek CSO ini kedepan dapat memberikan harapan terhadap perkembangan civil society di Indonesia. Kedua, Pemerintah Daerah belum memberikan ruang yang lebih luas bagi partisipasi LSM dalam perumusan kebijakan publik di Indonesia. Pelibatan LSM dalam perumusan kebijakan publik cenderung hanya untuk kebutuhan legitimasi semata. Ketiga, Secara umum tahapan-tahapan dalam perumusan APBD di Indonesia tidak dapat dimanfaatkan sebagai saluran informasi oleh semua stakeholders karena ketertutupan Pemda dan DPRD. Ketiadaan akses informasi oleh publik dalam perumusan APBD diyakini sebagai strategi Pemda dan DPRD untuk membatasi ruang gerak LSM terutama dalam melakukan advokasi dan berlangsung sampai pada tahap penetapan Rancangan APBD menjadi Perda APBD. Hal ini sengaja dikondisikan untuk melanggengkan dominasi Pemda dan DPRD dalam penyusunan APBD. 


\section{DAFTAR PUSTAKA}

Clark, John., 1995, NGO dan Pembangunan Demokrasi, (edisi terjemahan) PT. Tiara Wacana, Yogyakarta.

Diamond, Larry., 2003, Developing Democracy Toward Consolidation, Edisi Terjemahan, IRE Press, Yogyakarta.

Gaffar, Afan., 2004, Politik Indonesia Transisi menuju Demokrasi, Pustaka Pelajar, Yogyakarta.

Hikam, Muhammad AS., 1996, Demokrasi dan Civil Society, Pustaka LP3ES, Jakarta.

Huntington, Samuel, P. dan Nelson, Joan., 1994, Partisipasi Politik di Negara Berkembang, Edisi Terjemahan, Rineka Cipta, Jakarta.

Nawawi, Hadari, H., 2003, Metode Penelitian Bidang Sosial, Gadjah Mada University Press, Yogyakarta.

Putra, Fadillah., 2003, Paradigma Kritis Dalam Studi kebijakan Publik Perubahan dan Inovasi Kebijakan Publik dan Ruang Partisipasi Masyarakat Dalam Proses Kebijakan Publik, Pustaka Pelajar, Yogyakarta

Rinusu \& Sri Mastuti., 2003. Panduan Praktis Mengontrol APBD. Civic Education and Budget Transparancy Advocation (CiBa) dan Friedrich Ebert Stiftung (FES), Jakarta.

Sanit, Arbi, 1985, Swadaya Politik Masyarakat Telaah tentang Keterkaitan Organisasi Masyarakat, Partisipasi Politik, Pertumbuhan Hukum dan Hak Azasi, Radjawali, Jakarta.

Santoso, Purwo., dkk. (ed), 2004, Menembus Ortodoksi Kajian Kebijakan Publik, Fisipol UGM Yogyakarta.

Sastroatmodjo, Sudjono., 1995, Perilaku Politik, IKIP Semarang Press, Semarang.

Setiawan, Bonnie., 2000 Perjuangan Demokrasi dan Masyarakat Sipil, Reposisi dan Peran Ornop/LSM di Indonesia, INFID Jakarta,.

Sumarto, Hetifah Sj., 2003, Inovási, Partisipasi dan Good Governance, 20 Prakarsa Inovatif dan Partisipatif di Indonesi. Yayasan Obor Indonesia, Jakarta.

Surbakti, Ramlan., 2002, Memahami Ilmu Politik, Gramedia Widiasarana Indonesia, Jakarta

Suwondo, Kutut, 2003, Civil Society di Aras Lokal Perkembangan Hubungan Antara Rakyat dan Negara di Pedesaan Jawa, Pustaka Percik, Salatiga

Winarno, Budi., 2002, Teori dan Proses Kebijakan Publik, Media Presindo Yogyakarta. 